\title{
Poly-L/DL-lactic acid films functionalized with collagen IV as carrier substrata for corneal epithelial stem cells
}

\author{
Ana de la Mata ${ }^{\mathrm{a}, \mathrm{b}, *, 1,2}$, Miguel A. Mateos-Timoneda ${ }^{\mathrm{b}, \mathrm{c}, \mathrm{d}, 2}$, Teresa Nieto-Miguel ${ }^{\mathrm{a}, \mathrm{b}}{ }_{*}$, Sara Galindo $^{\mathrm{a}, \mathrm{b}}$, \\ Marina López-Paniagua ${ }^{a, b}$, Josep A. Planell ${ }^{c}$, Elisabeth Engel ${ }^{\text {, c, d, }}$, Margarita Calonge ${ }^{\mathrm{a}, \mathrm{b}}$ \\ a IOBA (Institute of Applied Ophthalmobiology), University of Valladolid, Valladolid, Spain \\ ${ }^{\mathrm{b}}$ Networking Research Center on Bioengineering, Biomaterials and Nanomedicine (CIBER-BBN). Carlos III National Institute of Health, Spain \\ ${ }^{c}$ Biomaterials for Regenerative Therapies Group, Institute for Bioengineering of Catalonia (IBEC), The Barcelona Institute of Science and Technology, Barcelona, Spain \\ d Department of Materials Science and Metallurgical Engineering, Technical University of Catalonia (UPC), Barcelona, Spain
}

\section{A R T I C L E I N F O}

\section{Keywords:}

Corneal epithelium

Collagen IV

Limbal stem cells

Polylactic acid

Tissue engineering

\begin{abstract}
A B S T R A C T
Limbal epithelial stem cells (LESCs) are responsible for the renewal of corneal epithelium. Cultivated limbal epithelial transplantation is the current treatment of choice for restoring the loss or dysfunction of LESCs. To perform this procedure, a substratum is necessary for in vitro culturing of limbal epithelial cells and their subsequent transplantation onto the ocular surface. In this work, we evaluated poly-L/DL-lactic acid 70:30 (PLA) films functionalized with type IV collagen (col IV) as potential in vitro carrier substrata for LESCs. We first demonstrated that PLA-col IV films were biocompatible and suitable for the proliferation of human corneal epithelial cells. Subsequently, limbal epithelial cell suspensions, isolated from human limbal rings, were cultivated using culture medium that did not contain animal components. The cells adhered significantly faster to PLA-col IV films than to tissue culture plastic (TCP). The mRNA expression levels for the LESC specific markers, K15, P63 $\alpha$ and ABCG2 were similar or greater (significantly in the case of K15) in limbal epithelial cells cultured on PLA-col IV films than limbal epithelial cells cultured on TCP. The percentage of cells expressing the corneal (K3, K12) and the LESC (P63 $\alpha$, ABCG2) specific markers was similar for both substrata. These results suggest that the PLA-col IV films promoted LESC attachment and helped to maintain their undifferentiated stem cell phenotype. Consequently, these substrata offer an alternative for the transplantation of limbal cells onto the ocular surface.
\end{abstract}

\section{Introduction}

The limbus, located at the transition zone between the cornea and the conjunctiva, is the niche for the maintenance and proliferation of limbal epithelial stem cells (LESCs), which are responsible for corneal epithelium regeneration [1]. This limbal niche is located in the palisades of Vogt, where the LESCs correspond to $10 \%$ of the basal cells [2] and are supported by the basement membrane and the underlying connective tissue. The limbal basement membrane provides cell support and improves the adhesion, growth, and proliferation of LESCs due to the associated extracellular matrix proteins, where type IV collagen (col IV) is the most abundant protein [3].
The destruction or dysfunction of LESCs or their limbal niche leads to a clinical entity known as limbal stem cell deficiency (LSCD). LSCD is characterized by the presence of unstable corneal epithelium and subsequent ulceration, invasion of the conjunctiva in the cornea, emergence of neovascularization on the corneal surface, and persistent inflammation and chronic pain, which ultimately causes vision loss and even corneal blindness [4,5]. Corneal transplantation is often the best option for vision recovery when the cornea is damaged, but it will not be successful if corneal damage is accompanied by the absence of viable LESCs. In this situation, restoration of the stem cell population is a possible treatment for LESC deficiency and must precede corneal transplantation. Cultivated limbal epithelial transplantation (CLET) for reconstruction of the damaged ocular surface in LSCD syndrome was first reported in 1997 [6]. Subsequently, this strategy has been used by

\footnotetext{
* Corresponding authors.

Email addresses: adelamatas81@gmail.com (A. de la Mata); tnietom@ioba.med.uva.es (T. Nieto-Miguel)

1 Present address: Institute for Neuroscience of Castile and Leon (INCyL), University of Salamanca, Salamanca, Spain.

2 These authors contributed equally to this work.
} 
many other authors [7-10]. To perform CLET, a substratum is necessary for both in vitro expansion of epithelial cells and the subsequent transplantation onto the ocular surface. Biological substrata such as fibrin $[9,11]$, human amniotic membrane [10,12-14], and cellular feeder layers such as 3T3 fibroblasts [6] have been used to facilitate the expansion of corneal epithelial cells. However, as natural products, none of these agents can be standardized, and they are not optically transparent. Furthermore, the risk of disease transmission, the limited availability of these products, and the high economic cost [15] necessitate the investigation of a new substrata for LESCs.

An ideal biomaterial for proliferation and transplantation of LESCs onto the ocular surface would be biocompatible [16], biodegradable, optically clear, sturdy enough to be handled and withstand suturing, possess low immunogenicity, and would not induce cell differentiation. Moreover, these biomaterials should resemble the structure and properties of the natural LESC niche to provide an ideal environment for in vitro culturing of such cells. Various polymeric biomaterials have been described as alternatives to natural materials as substrates or scaffolds for stem cells. Biosynthetic materials like polycaprolactone [17], polylactic glycolic acid, chitosan and gelatin membranes [18], collagen gels [16,19-21] or elastin like polymers [22] have been used to support ocular epithelial cells. Levis et al. described the use of collagen constructs for the support of LESCs previously isolated on 3T3 fibroblasts for obtaining a stratified corneal epithelium [21]. The same group also described the use of a surface-modified contact lens to support LESCs previously expanded on 3T3 fibroblasts [23]. Other groups have also used type I collagen scaffolds, with embedded stromal fibroblasts, as substrata for LESCs $[24,25]$.

Besides the substrata mentioned above, there are other systems in which a corneal epithelial cell sheet for transplantation can be acquired without using a carrier. One of these systems is the Mebiol gel, which remains liquid at temperatures below $20^{\circ} \mathrm{C}$, and gels over $20^{\circ} \mathrm{C}[26,27]$. Yang et al. proposed the use of thermosensitive culture plates, in which changing the temperature allows for the growth of an epithelial cell sheet without any enzymatic action, keeping the synthesized extracellular matrix intact [28].

Among the various materials available, a polylactic acid derivative is one of the preferred choices. Polylactic acid is a lactic acid derivative that can take on different mechanical properties by varying its structure and altering its crystallinity degree [29]. It is known to be a biocompatible and biodegradable material of which the degradation products, mainly carbon dioxide and water, are not toxic to the organism [30]. Polylactic acid has been used in several biomedical applications, such as absorbable sutures, a transport medium for drug delivery, and tissue engineering [29,31]. Currently, the use of polylactic acid has expanded significantly in the field of bone regeneration [32-34] and combined with glycolic acid (polylactic-glycolic acid) in conjunctival and corneal reconstruction [35-37]. However, it has been demonstrated that cell adhesion to polylactic acid films is poor, and that it is necessary to functionalize the surface of this type of polymer to improve cell attachment $[38,39]$. Col IV is an extracellular matrix protein described in the limbal, corneal, and conjunctival epithelial basement membranes, specifically in the basement membrane of the limbal epithelium. The $\alpha 1$ and $\alpha 2$ chains of col IV have been repeatedly described as limbal zone-specific and they are not expressed in the differentiated corneal epithelial basement membrane $[3,40,41]$. This type of collagen has been used to select populations of LESCs based on their rapid adhesion to this protein. Additionally, cells with greater adherence to col IV mainly expressed undifferentiated LESC markers, where the expression of differentiated corneal epithelial markers was decreased [42].

Based on these alternatives, the present work aimed to replace the biological substrates and culture techniques currently used for culturing and transplanting LESCs onto the ocular surface with synthetic biopolymers, avoiding the use of any animal components, in both the substratum and in the culture medium for limbal epithelial cells. Additionally, to avoid the use of murine 3T3 fibroblasts to expand LESCs, the surface of these polymers was functionalized with a human extracellular matrix protein to promote cell adhesion to the substratum. The goal of this work was to evaluate the suitability of poly-L/DL-lactic acid 70:30 (PLA) films functionalized with col IV (PLA-col IV) as potential carrier substrata for human LESCs.

\section{Material and methods}

\subsection{Reagents}

Poly-L/DL lactic acid 70/30 (Purasorb PLDL 70/38, inherent viscosity midpoint $3.8 \mathrm{dl} / \mathrm{g}$, Mw 850,000 Da) (PLA from now on) was purchased from Purac Biomaterials (Amsterdam, The Netherlands). Phosphate-buffered saline solution (PBS), Hanks balanced salt solution, trypsin-ethylenediamine-tetraacetic acid (EDTA) 1X, Versene, Dulbecco's modified Eagle's medium (DMEM/F12), fetal bovine serum (FBS), epidermal growth factor (EFG), human insulin, penicillin/streptomycin, gentamicin, and fungizone were purchased from Invitrogen-Gibco (Inchinan, UK). Human serum and cholera toxin were purchased from Lonza (Basel, Switzerland) and Gentaur (Kanpenhout, Belgium), respectively. The Viability-Cytotoxicity Assay Kit for Mammalian Live and Dead Cells was purchased from Biotium, Inc. (Hayward, CA, USA), and the proliferation assay kit Alamar Blue ${ }^{\mathrm{TM}}$ was purchased from AbD Serotec (Oxford, UK). Col IV from human placenta (C7521) and all the other reagents were purchased from Sigma-Aldrich (St Louis, MO, USA) and used without further purification. The Micro BCA ${ }^{\mathrm{TM}}$ Protein Assay Kit was purchased from Thermofisher Scientific (Waltham, MA, USA).

\subsection{PLA films fabrication}

PLA films were obtained by solvent casting. Briefly, PLA was dissolved in $\mathrm{CHCl}_{3}(2.5 \% \mathrm{w} / \mathrm{v})$ and was poured into Petri dishes with a diameter of $12 \mathrm{~cm}$. The solvent was allowed to evaporate for 3 days in a solvent-saturated atmosphere. After this time, the obtained films were stored in a vacuum and dry atmosphere until their use. The thickness of the resulting films was $100 \mu \mathrm{m}$.

\subsection{PLA films functionalization with col IV}

The surface functionalization of the PLA films with col IV was carried out following previously developed protocols [38,39]. In short, PLA films were treated with sodium hydroxide $0.5 \mathrm{M}$ for $30 \mathrm{~min}$ to hydrolyze the surface of the films. After extensively rinsing with water, the films were activated with $\mathrm{N}$-(3-dimethylaminopropyl)-N'-ethylcarbodiimide and N-hydroxysuccinimide (EDC and NHS) 0.1/0.2 M in PBS (pH 7.4) for $1 \mathrm{~h}$. Further, films were washed twice with PBS, and col IV was covalently attached to the surface of the material, incubating the films in a PBS col IV solution at $20 \mu \mathrm{g} / \mathrm{ml}$ overnight. Finally, functionalized films were washed again with water and vacuum sealed until their use.

\subsection{PLA-col IV films physico-chemical characterization}

The physico-chemical characterization of the PLA films during the different steps of the functionalization process has already been reported elsewhere [39]. Contact angle (CA) measurements were carried out with an optical contact angle device (OCA15, Dataphysics, Germany) before and after col IV functionalization of the PLA films.

Immunofluorescence was used to determine the presence of col IV on the surface of the PLA films. In brief, the samples were blocked for $20 \mathrm{~min}$ at room temperature with PBS-Glycine-bovine serum albumin. 
After washing with PBS-Glycine $(2 \times 5 \mathrm{~min})$, the samples were incubated with the primary antibody (Table 2) for $45 \mathrm{~min}$ at $37^{\circ} \mathrm{C}$ and washed with PBS-Glycine $(2 \times 5 \mathrm{~min})$. The incubation of the secondary antibody (Table 2) was performed in the dark over $45 \mathrm{~min}$ at $37^{\circ} \mathrm{C}$. The samples were visualized with a Nikon E600 upright fluorescence microscope (Tokyo, Japan). Different controls were performed by incubation of either only primary or secondary antibodies.

For col IV quantification, a Micro BCA ${ }^{\mathrm{TM}}$ Protein Assay Kit was used, following the manufacturer's protocol. The experiment was conducted in triplicate with six replicas per experiment.

\subsection{Human corneal epithelial (HCE) cell culture}

With the aim of delimitating a culture area of $1 \mathrm{~cm}^{2}$ and preventing the polymer film from floating, reusable cell culture inserts made of silicone (flexiPERM, Sigma Aldrich) were used. The flexiPERM was gently pressed against the dry polymer film or the control tissue culture plastic (TCP) before cell culture.

Simian virus-40-transformed HCE cells [43] (a kind gift from Arto Urtti, University of Helsinki, Finland) were used in passage 40-48 to test the polymer as cellular substratum. A total of $4 \times 10^{4}$ cells $/ \mathrm{cm}^{2}$ were seeded on the TCP and on each biopolymer and cultured using DMEM/ F12 culture medium supplemented with $15 \% \mathrm{FBS}, 0.5 \%$ DMSO, $0.1 \mu \mathrm{g} /$ $\mathrm{ml}$ cholera toxin, $10 \mathrm{ng} / \mathrm{ml} \mathrm{EGF}, 5 \mu \mathrm{g} / \mathrm{ml}$ human insulin, and antibiotics $(62.5 \mathrm{U} / \mathrm{ml}$ penicillin, $62.5 \mathrm{mg} / \mathrm{ml}$ streptomycin). The cells were incubated at $37^{\circ} \mathrm{C}$, under $5 \% \mathrm{CO}_{2}$ and $95 \%$ humidified air. The culture medium was carefully changed every $2-3$ days.

\subsection{HCE cell viability}

The viability of HCE cells grown on the PLA-col IV film was analyzed at $6 \mathrm{~h}$ and at $1,2,4$, and 8 days. Cellular viability-cytotoxicity assays were performed on attached cells by using the Viability-Cytotoxicity Assay Kit for Mammalian Live and Dead Cells. The kit uses a combination of calcein-AM and ethidium homodimer (EthD-III) to dye live cells green and dead cells red. At each time point, the culture medium was gently removed and cells were washed with PBS. After staining according to the manufacturer's instructions, the cultures were rinsed with PBS prior to being viewed under a fluorescence microscope (Leica DMI $6000 \mathrm{~B}$, Leica, Wetzlar, Germany). Live and dead cells were counted in 5 random fields per substratum and time. Viability was expressed as the percentage of live cells \pm standard error of the mean (SEM) from 4 independent experiments.

\subsection{HCE cell proliferation}

Cell growth was determined by using the fluorometric non-toxic Alamar Blue ${ }^{\mathrm{TM}}(\mathrm{AB})$ assay, which depends on the conversion of resazurin to resorufin, a pink fluorescent dye. The reaction is based upon chemical reduction of the culture medium resulting from cell growth. The $\mathrm{AB}$ assay was performed after $1,2,4$, and 8 days according to the manufacturer's instructions. After $5 \mathrm{~h}$ of incubation, duplicate $300 \mu \mathrm{l}$ samples of culture medium for each test sample were transferred to a 24-well plate. Fluorescence was measured on a SpectraMAx M5 (Molecular Devices, Sunnyvale, CA, USA) at an excitation wavelength of $560 \mathrm{~nm}$ and emission wavelength of $590 \mathrm{~nm}$, according to the specifications of the manufacturer.

A total of $4 \times 10^{4}$ cells $/ \mathrm{cm}^{2}$ were seeded onto TCP and the PLA-col IV film. To consider only the cells adhered to the biopolymers, the polymeric membranes were transferred to another clean well. Proliferation data were expressed as the relative cell density reached after 8 days compared to the cell density at 1 day from 4 independent experiments.

\subsection{Human limbal epithelial cell isolation and culture}

The following protocols were approved by the IOBA Research Committee and the Valladolid Medical School Ethics Committee. Human tissues were always handled according to the Tenets of Declaration of Helsinki.

Cadaveric human corneoscleral buttons were obtained under informed research consent from Barraquer Eye Bank of Barcelona (Spain). The average age \pm SEM of the donors was $75.6 \pm 2.5$ years. The buttons were stored at $4{ }^{\circ} \mathrm{C}$ and were used within $3 \pm 0.2$ days of the donor's death.

Human limbal epithelial cells were grown from single cellular suspensions obtained from corneoscleral buttons, as described previously [44]. Briefly, the corneoscleral tissue from 11 different donors was rinsed with Hanks balanced salt solution containing $50 \mu \mathrm{g} / \mathrm{ml}$ gentamicin and $2.5 \mu \mathrm{g} / \mathrm{ml}$ fungizone. The excess of conjunctiva, iris, and corneal endothelium tissues were carefully removed, and a $7.5 \mathrm{~mm}$ trephine was used to isolate the central cornea from the limbus. Then, limbal rings were excised in two pieces and each piece was incubated at $37^{\circ} \mathrm{C}$ for $2 \mathrm{~h}$ with dispase enzyme $(1.2 \mathrm{U} / \mathrm{ml})$, which digests the basement membrane collagen and separates epithelial cells from the stroma. Then, the limbal epithelial cells were collected and treated with trypsin $(0.25 \%)$ for $10 \mathrm{~min}$ at $37^{\circ} \mathrm{C}$ to separate them into a suspension of single cells. The single cells were seeded on PLA-col IV and TCP at a density of $4 \times 10^{4}$ cells $/ \mathrm{cm}^{2}$. To improve the cell adhesion on the substrata, cells were maintained for $2 \mathrm{~h}$ with $200 \mu \mathrm{l}$ (in $1 \mathrm{~cm}^{2}$ ) of culture medium, based on DMEM/F12 supplemented with $10 \%$ human serum, $5 \mathrm{ng} / \mathrm{ml} \mathrm{EGF}, 5 \mu \mathrm{g} / \mathrm{ml}$ human insulin, $0.4 \mu \mathrm{g} / \mathrm{ml}$ hydrocortisone, $1 \mu \mathrm{M}$ isoproterenol, $0.18 \mathrm{mM}$ adenine, $2 \mathrm{nM}$ triiodothyronine, $50 \mu \mathrm{g} / \mathrm{ml}$ gentamicin, and $2.5 \mu \mathrm{g} / \mathrm{ml}$ fungizone [18]. After $2 \mathrm{~h}$, a total of $500 \mu \mathrm{l}$ of culture medium were added, and the total amount of $1 \mathrm{ml} / \mathrm{cm}^{2}$ was added when cells were attached.

All cultures were incubated at $37^{\circ} \mathrm{C}$ in a humidified atmosphere containing $5 \% \mathrm{CO}_{2}$. The medium was freshly replaced every 2-3 days, and the cultures were monitored using a phase contrast microscope (Eclipse TS100, Nikon). The time when single cells started to adhere and reach confluence was recorded.

\subsection{Real-time reverse transcriptase polymerase chain reaction (RT-PCR)}

Real-time RT-PCR was performed to determine the expression levels of specific corneal and limbal genes. Cytokeratins 3 (K3) and 12 (K12) are differentiated corneal epithelial cell cytoskeletal markers [45-47]. Cytokeratin 15 (K15) [13], the transcription factor P63 $\alpha$ (P63 $\alpha$ ) [48], and the ATP-binding cassette transporter G2 (ABCG2) [49] are LESC markers [50]. Limbal epithelial cells grown from the single cell suspension were harvested at confluence. Total RNA was isolated using the RNeasy ${ }^{\circledR}$ Mini Kit (Qiagen, Valencia, CA, USA) according to specifications of the manufacturer. The RNA concentration was measured by a fluorometric method using the Quant-iT RNA assay and treated with RNase-Free DNase Set (Qiagen).

Total RNA $(1 \mu \mathrm{g})$ was retrotranscribed to cDNA using SuperScript ${ }^{\circledR}$ Vilo $^{\text {TM }}$ cDNA Synthesis Kit (Invitrogen-Gibco, UK). The RNA was mixed with 5X Vilo Reaction Mix and 10X Superscript Enzyme Mix (7:1:2) and thermocycled at $25^{\circ} \mathrm{C}$ for $10 \mathrm{~min}$, at $42{ }^{\circ} \mathrm{C}$ for $120 \mathrm{~min}$, and finally at $85^{\circ} \mathrm{C}$ for $5 \mathrm{~min}$. PCR amplifications using specific probes (Table 1) were performed in a PCR 7500 Real Time PCR System (Applied Biosystems, Carlsbad, CA, USA) according to specifications of the manufacturer.

All experiments were performed in duplicate. A non-template negative control was included in all experiments to evaluate DNA and RT-PCR contamination of the reagents. Glyceraldehyde-3-phosphate dehydrogenase (GAPDH) was used as a housekeeping gene for each reac- 
Table 1

Taqman probes used for real-time PCR analysis.

\begin{tabular}{lll}
\hline Gene name & Symbol & $\begin{array}{l}\text { Identification number of Applied } \\
\text { Biosystems }\end{array}$ \\
\hline $\begin{array}{l}\text { Glyceraldehide-3-phosphate } \\
\text { dehydrogenase }\end{array}$ & GAPDH & 4352934E \\
$\begin{array}{l}\text { ATP-binding cassette transporter } \\
\text { G2 }\end{array}$ & ABCG2 & Hs00184979_m1 \\
$\begin{array}{l}\text { Cytokeratin 3 (K3) } \\
\text { Cytokeratin 12 (K12) } \\
\begin{array}{l}\text { Cytokeratin 15 (K15) } \\
\text { Transcription factor P63 } \alpha\end{array}\end{array}$ & K3 & Hs00365080_m1 \\
\hline
\end{tabular}

Table 2

Primary and secondary antibodies used for immunofluorescence staining.

\begin{tabular}{|c|c|c|c|c|}
\hline Antibodies & Category & $\begin{array}{l}\text { Catalog } \\
\text { No. }\end{array}$ & Source & $\begin{array}{l}\text { Working } \\
\text { dilution }\end{array}$ \\
\hline \multicolumn{5}{|l|}{ PRIMARY } \\
\hline $\begin{array}{l}\text { Cytokeratin } \\
\text { AE5 (K3) }\end{array}$ & $\begin{array}{l}\text { Mouse } \\
\text { (monoclonal) }\end{array}$ & 69143 & $\begin{array}{l}\text { Mp Biomedical } \\
\text { (Illkirch, France) }\end{array}$ & $1: 50$ \\
\hline $\begin{array}{l}\text { Cytokeratin } 12 \\
\text { (K12) }\end{array}$ & $\begin{array}{l}\text { Rabbit } \\
\text { (polyclonal) }\end{array}$ & 25722 & $\begin{array}{l}\text { Sta Cruz } \\
\text { (Heidelberg, } \\
\text { Germany) }\end{array}$ & $1: 50$ \\
\hline $\begin{array}{l}\text { Cytokeratin } 15 \\
\text { (K15) }\end{array}$ & $\begin{array}{l}\text { Mouse } \\
\text { (monoclonal) }\end{array}$ & CBL272 & $\begin{array}{l}\text { Chemicon/Millipore } \\
\text { (Billerica, MA, USA) }\end{array}$ & $1: 50$ \\
\hline ABCG2 & $\begin{array}{l}\text { Mouse } \\
\text { (monoclonal) }\end{array}$ & MAB4146 & $\begin{array}{l}\text { Chemicon/Millipore } \\
\text { (Billerica, MA, USA) }\end{array}$ & $1: 20$ \\
\hline $\mathrm{P} 63 \alpha$ & $\begin{array}{l}\text { Rabbit } \\
\text { (polyclonal) }\end{array}$ & 4892 & $\begin{array}{l}\text { Cell Signaling } \\
\text { (Boston, MA, USA) }\end{array}$ & $1: 50$ \\
\hline Col4 A & $\begin{array}{l}\text { Mouse } \\
\text { (monoclonal) }\end{array}$ & & $\begin{array}{l}\text { Santa Cruz } \\
\text { (Heidelberg, } \\
\text { Germany) }\end{array}$ & $1: 100$ \\
\hline \multicolumn{5}{|l|}{ SECONDARY } \\
\hline $\begin{array}{l}\text { Anti-mouse } \\
\text { IgG } \\
\text { Alexa fluor } \\
488\end{array}$ & Donkey & & $\begin{array}{l}\text { Invitrogen } \\
\text { (Inchinnan, UK) }\end{array}$ & $1: 200$ \\
\hline $\begin{array}{l}\text { Anti-rabbit } \\
\text { IgG } \\
\text { Alexa fluor } \\
488\end{array}$ & Donkey & & $\begin{array}{l}\text { Invitrogen } \\
\text { (Inchinnan, UK) }\end{array}$ & $1: 300$ \\
\hline $\begin{array}{l}\text { Anti-mouse } \\
\text { IgG } \\
\text { Alexa fluor } \\
488\end{array}$ & Goat & & $\begin{array}{l}\text { Invitrogen } \\
\text { (Inchinnan, UK) }\end{array}$ & $1: 250$ \\
\hline
\end{tabular}

tion. The comparative cycle threshold (Ct) method (Applied Biosystems User Bulletin, No.2; P/N 4,303,859) was used to analyze the results [51]. Six independent experiments from different donors were carried out.

\subsection{Immunofluorescence staining}

Cultured cells were harvested by incubation in Versene for $30 \mathrm{~min}$ at $37^{\circ} \mathrm{C}$. A total of 50,000 cells in $250 \mu$ l of DMEM-F12 were pelleted by cytocentrifugation for $10 \mathrm{~min}$ at $800 \mathrm{rpm}$ using low acceleration. Cells were deposited onto a $28 \mathrm{~mm}^{2}$ area of a poly-L-lysine-treated glass slide and fixed with cold methanol at $-20^{\circ} \mathrm{C}$ for $10 \mathrm{~min}$.

For immunofluorescence staining, the cells were incubated for $1 \mathrm{~h}$ at room temperature with blocking buffer (5\% donkey serum in PBS). The cells were then incubated with primary antibody (Table 2) in a humidified chamber at $4{ }^{\circ} \mathrm{C}$ overnight. Afterwards, they were rinsed with PBS and incubated with the secondary antibody (Table 2) in the dark at $37^{\circ} \mathrm{C}$ for $1 \mathrm{~h}$. Nuclei were counterstained with propidium iodide and the samples were analyzed under fluorescent microscope (Leica DMI 6000 B, Leica).

Positively and negatively stained cells in 5 random fields of 4 independent limbal epithelial cultures were counted. The percentage of positive cells was calculated for each field, and the mean percentage of positive cells for each marker was determined.

\subsection{Statistical analysis}

Statistical significance was determined by one-way factorial ANOVA. Comparison between two groups was made using Student's t-test. All values were expressed as means \pm SEM. P-values $\leq 0.05$ were considered statistically significant.

\section{Results}

\subsection{Functionalization of $p$ PLA films with col IV}

The PLA and PLA-col IV substrata were obtained as transparent films (Fig. 1, left). The functionalization process with col IV did not alter the transparency, handleability and suturability of the films. The physico-chemical characterization and optimization of the different steps of the functionalization process had been described elsewhere. CA measurements were performed to evaluate the changes in hydrophobicity before and after the functionalization with col IV. The CA of a pristine PLA is $78.8 \pm 1.9^{\circ}$, as expected for a slightly hydrophobic polymer. However, the contact angle decreased to a value of $53.0 \pm 11.0^{\circ}$ upon covalent binding of col IV. Immunofluorescence was performed to investigate the presence of immobilized col IV in the surface of the materials (Fig. 1, right). Both controls using only the primary or secondary antibodies, and in samples of pristine PLA, showed no fluorescence, indicating the selectivity of the proposed method for the detection of immobilized col IV on the surface of the PLA-col IV films.

The quantification of col IV in the surface of the materials was performed by a microBCA assay. PLA discs of $1.5 \mathrm{~cm}$ of diameter were
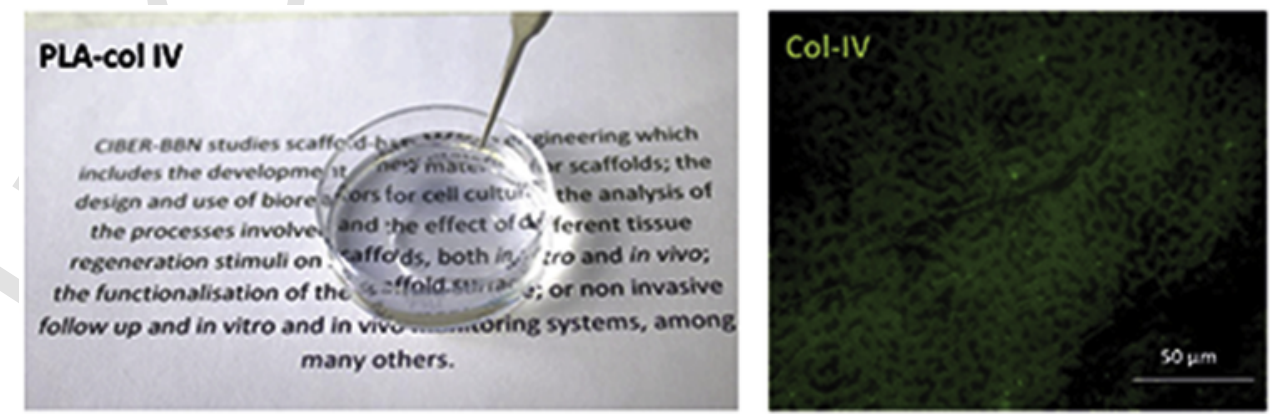

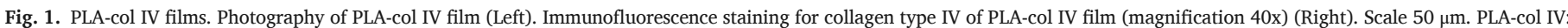
poly-L/DL-lactic acid 70:30 biopolymers functionalized with type IV collagen. 
functionalized following the previously described protocol. The results showed that $8.3 \pm 1.3 \mu \mathrm{g} / \mathrm{cm}^{2}$ of col IV were grafted to the surface of the material, which corresponds to a grafting yield of $73.5 \%$.

\subsection{Limbal epithelial cell adhesion to bare PLA films}

Taking into account that we had previously observed poor cell adhesion to bare PLA substrata using different cell types [38,39] we decided to first test the adhesion capacity of limbal epithelial cells to bare PLA films in order to evaluate if the PLA films without col IV could serve as control substrata for the subsequent studies. To that end, limbal epithelial cells isolated from human limbal rings were cultured on bare PLA films and on TCP. As we expected, limbal epithelial cells did not adhere to the surface of PLA films whereas they did adhere to TCP after 24-48 h (data not shown). Consequently, PLA films without col IV were not used as control substrata in any experiment.

\subsection{HCE cell viability and proliferation on PLA-col IV films}

HCE cells were grown onto membranes composed of PLA-col IV and TCP as control substratum.

The cell viability was around $90 \%$ (Table 3 ) for the 8-day study period, and no significant differences were observed between both substrata.

HCE cell proliferation on each substratum was assessed by $A B$ testing at $1,2,4$, and 8 days in culture. The relative cell density reached at 8 days onto TCP (as control substratum) was significantly higher than the cell density on PLA-col IV membranes at 8 days ( $<<0.05$ ) (Fig. 2).

Table 3

Cell viability of the human corneal epithelial cell line (HCE).

\begin{tabular}{|c|c|c|c|c|}
\hline \multirow[t]{2}{*}{ Substrata } & \multicolumn{4}{|c|}{ Cell viability (\%) } \\
\hline & 1 day & 2 days & 4 days & 8 days \\
\hline TCP & $98 \pm 0.002$ & $99 \pm 0.001$ & $97 \pm 0.010$ & $99 \pm 0.007$ \\
\hline PLA-col IV & $98 \pm 0.007$ & $99 \pm 0.004$ & $95 \pm 0.010$ & $85 \pm 0.030$ \\
\hline
\end{tabular}

TCP: tissue culture plastic; PLA-col IV: poly-L/DL-lactic acid 70:30 biopolymers functionalized with type IV collagen. Mean \pm SEM based upon cell counts of 5 random fields of 4 independent experiments.

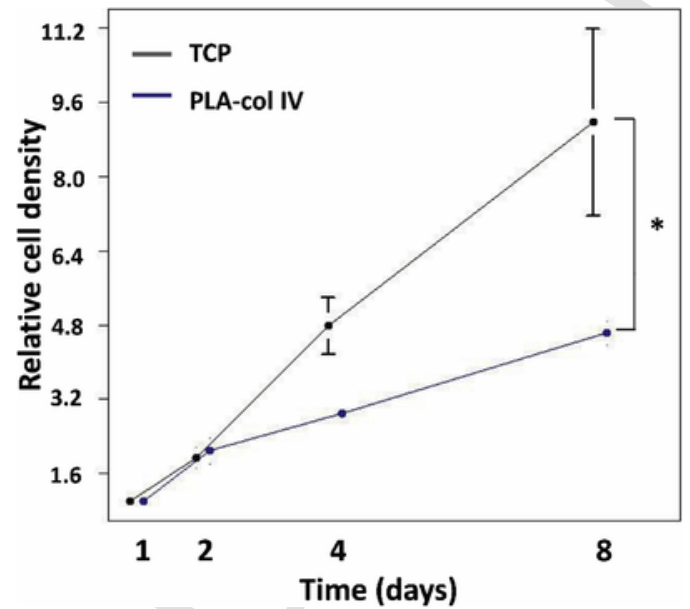

Fig. 2. PLA-col IV films are suitable for the proliferation of HCE cells. Plot representing the relative cell density reached on TCP (gray, up) and PLA-col IV (blue, down) along 8 days, compare to the density at day 1 . Plot represents the average \pm SEM $(\mathrm{N}=4$ independent experiments). ${ }^{*} \mathrm{p}<0.05,{ }^{* *} \mathrm{p}<0.01,{ }^{* * *} \mathrm{p}<0.001$. PLA-col IV: poly-L/DL-lactic acid 70:30 biopolymers functionalized with type IV collagen; HCE: human corneal epithelium; TCP: tissue culture plastic.

\subsection{Limbal epithelial cell isolation and expansion on PLA-col IV films}

A population of limbal epithelial cells was cultured on different films of PLA-col IV and TCP as control substratum. For both substrata, the outgrowth was developed as a monolayer of cells. The cells were morphologically homogeneous, presenting a polygonal structure typical of epithelial cells.

Cell adhesion of the single cell suspension obtained from human limbal rings started after $2 \mathrm{~h}$ from seeding on PLA-col IV, and after 24-48 hours when they were cultured on TCP (Fig. 3A), observing a significant difference $(\mathrm{p}<0.01)$. Cellular confluence $\left(1 \mathrm{~cm}^{2}\right)$ was observed at $9.4 \pm 1.0$ days on PLA-col IV, and after $10.1 \pm 0.9$ days on TCP (Fig. 3B). No significant differences were found to reach confluence on PLA-col IV and TCP at the different time points. However, adhesion was better on the PLA-col IV films than on the control substratum. These results suggest that the substratum PLA-col IV improves the human limbal epithelial cell adhesion and did not affect the growth of limbal epithelial cells compared to TCP.

\subsection{Characterization of the limbal epithelial cell population obtained on PLA-coI IV films}

The relative expression of cytokeratins $\mathrm{K} 3$ and $\mathrm{K} 12$ (as markers of differentiated corneal epithelial cells) and the expression of K15, the transcription factor P63 $\alpha$ and the transport protein ABCG2 (as LESC markers) was analyzed by real-time PCR in limbal primary cultures cultivated on PLA-col IV films and TCP.

In order to compare the expression levels of the different markers (Table 1) between TCP and PLA-col IV, the mRNA relative expression of the different markers was analyzed by using the expression of $\mathrm{K} 3$ in cells cultured on TCP as calibrator (Fig. 4A). In this case, the relative expression of K15 on PLA-col IV (1122.1 \pm 86.6 fold) was significantly higher $(p<0.01)$ than the expression on TCP $(713.4 \pm 197.4$ fold $)$. Furthermore, the expression of $\mathrm{K} 15$ was significantly higher than the expression of all the rest of the markers $(\mathrm{p}<0.001)$. In case of the transcription factor P63 $\alpha$, no differences were observed between TCP $(95.3 \pm 13.8$ fold) and PLA-col IV (97.3 \pm 11.7 fold).

On the other hand, the expression of K12 was significantly higher $(\mathrm{p}<0.05)$ in the biopolymer $(439.8 \pm 135.5$ fold $)$ than in TCP $(178.3 \pm 80.6$ fold $)$. Moreover, K12 expression was higher than the ABCG2 and K3 expression when limbal epithelial cells were cultured on PLA-col IV.

Subsequently, the expression of K3 in cells cultured on PLA-col IV was used as calibrator to compare the expression levels of the different markers in cells cultured on PLA-col IV films (Fig. 4B). The relative expression of K15 in cells cultured on PLA-col IV ( $68.5 \pm 5.3$ fold) was significantly higher $(\mathrm{p}<0.001)$ than the expression of $\mathrm{K} 3$ ( $1 \pm 0$ fold $)$, K12 (26.8 \pm 8.3 fold), ABCG2 (1.4 \pm 0.4 fold) and P63 $\alpha$ (5.9 \pm 0.7 fold). The relative expression of P63 $\alpha$ (5.9 \pm 0.7 fold) was also significantly higher $(\mathrm{p}<0.01)$ than the K3 and ABCG2 expression in cells cultured on the tested biopolymer. Moreover, K12 expression was significantly higher $(\mathrm{p}<0.05)$ than the $\mathrm{K} 3$ expression when limbal epithelial cells were cultured on PLA-col IV. These expression levels detected in the cells cultured on PLA-col IV films indicate the presence of a stem-cell-rich limbal epithelial cell population.

The expression of the same markers in cells cultured on PLA-col IV films and TCP was also studied by immunofluorescence. In this case, the results were expressed in percentage of positive cells for each marker (Fig. 5). The specific limbal epithelial cytokeratin K15 was expressed in about $29.4 \% \pm 0.1$ of cells on PLA-col IV, which is significantly lower that the percentage of cells that expressed K3 $(\mathrm{p}<0.01)$, K12 ( $\mathrm{p}<0.001)$ and ABCG2 ( $<0.01)$. However, no significant differences were found between the expression of ABCG2 compared with 
A
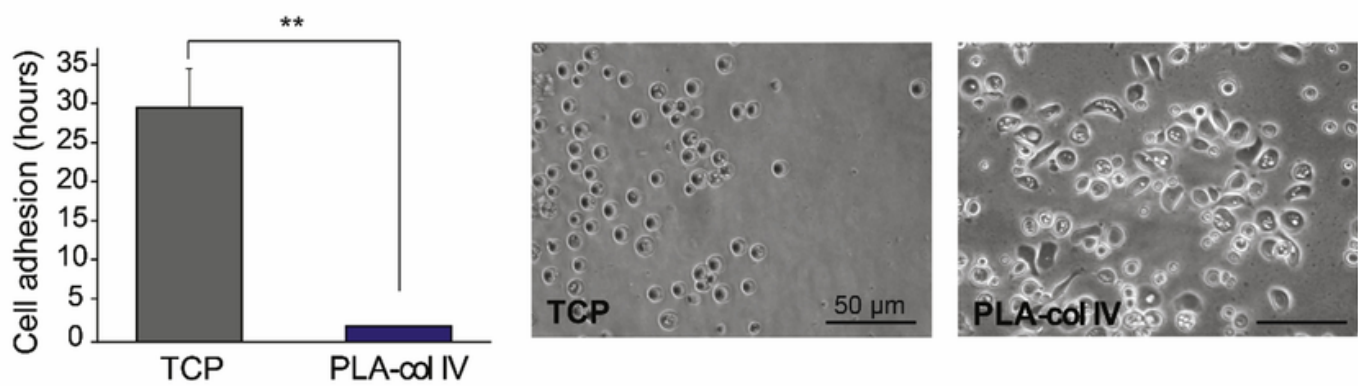

B
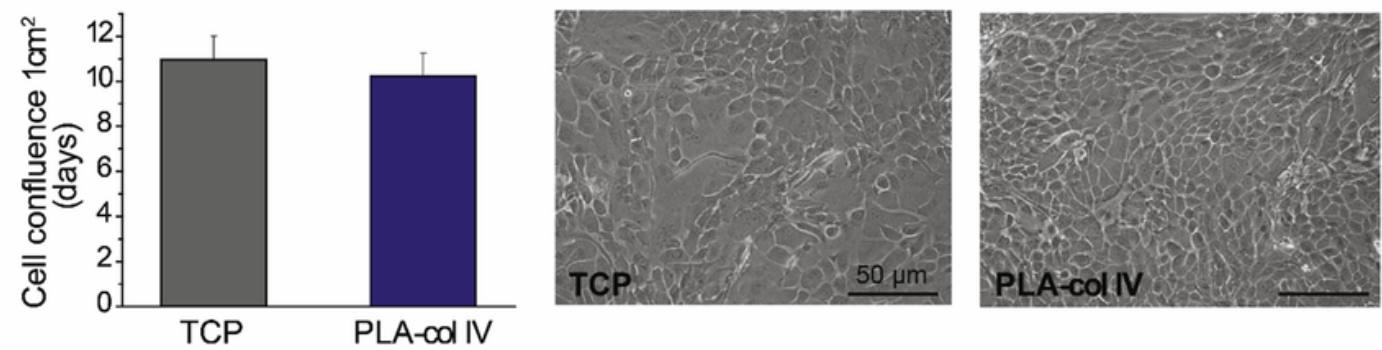

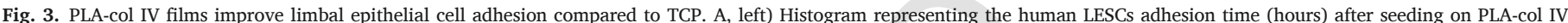

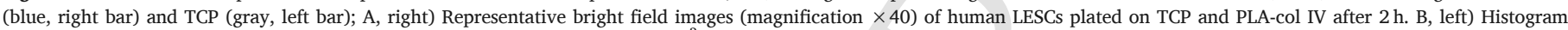

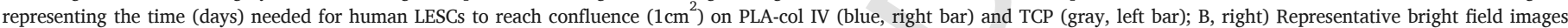

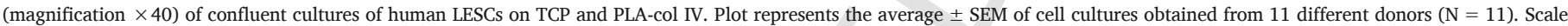
$50 \mu \mathrm{m} .{ }^{*} \mathrm{p}<0.05,{ }^{* *} \mathrm{p}<0.01,{ }^{* * *} \mathrm{p}<0.001$. PLA-col IV: poly-L/DL-lactic acid 70:30 biopolymers functionalized with type IV collagen; TCP: tissue culture plastic.

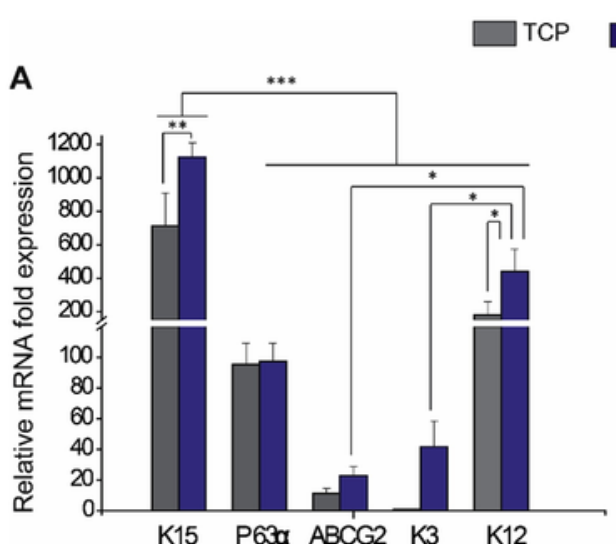

PLA-col IV

B

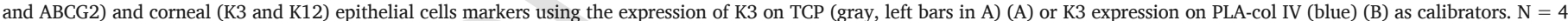

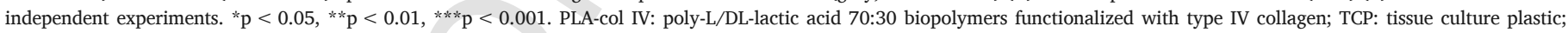
LESC: limbal epithelial stem cell.

$\mathrm{K} 3$ and $\mathrm{K} 12$, showing $78.3 \% \pm 0.1$ positive cells for ABCG2, and $80.9 \%$ \pm 0.1 and $96.2 \% \pm 0.0$ positive cells for K3 and K12, respectively (Fig. 5). Otherwise, a high percentage of cells expressed the transcription factor P63 $\alpha(36.9 \% \pm 0.1)$, described in limbal epithelial stem cells.

\section{Discussion}

In the present work, PLA biopolymers, functionalized with col IV, were evaluated as potential carrier substrata for the culture and further transplantation of LESCs to the ocular surface. These PLA-col IV films ensured enough flexibility and transparency to make this biomaterial ideal for use in tissue engineering. In addition, PLA is biocompatible and biodegradable, and it is known that its degradation products are non-toxic. Several analogs of PLA have been used in different biomedical applications as well as in advanced therapy drugs in tissue engi- neering. In the field of ophthalmology, some members of the PLA family (pure or combined with other materials) are being used in preclinical studies [37]. However, it is known that PLA alone is not adequate for the adhesion of some cell types [38,39].

To improve cell attachment to PLA, we functionalized the films with a human extracellular matrix protein. It has been described that the limbal epithelial basal membrane has several extracellular matrix proteins. These proteins are secreted by stromal and limbal epithelial cells, and they are essential for the adhesion of LESCs. Among all the proteins, col IV $\alpha 1$ and $\alpha 2$ chains have been described as the specific proteins in the limbal area, and they are not present in the differentiated corneal epithelial basal membrane [3,40,41]. Additionally, type IV col has been used to select LESC populations based on their fast attachment to these surfaces. It has also been demonstrated that cells containing higher col IV-adhesion properties mainly expressed LESC 
A
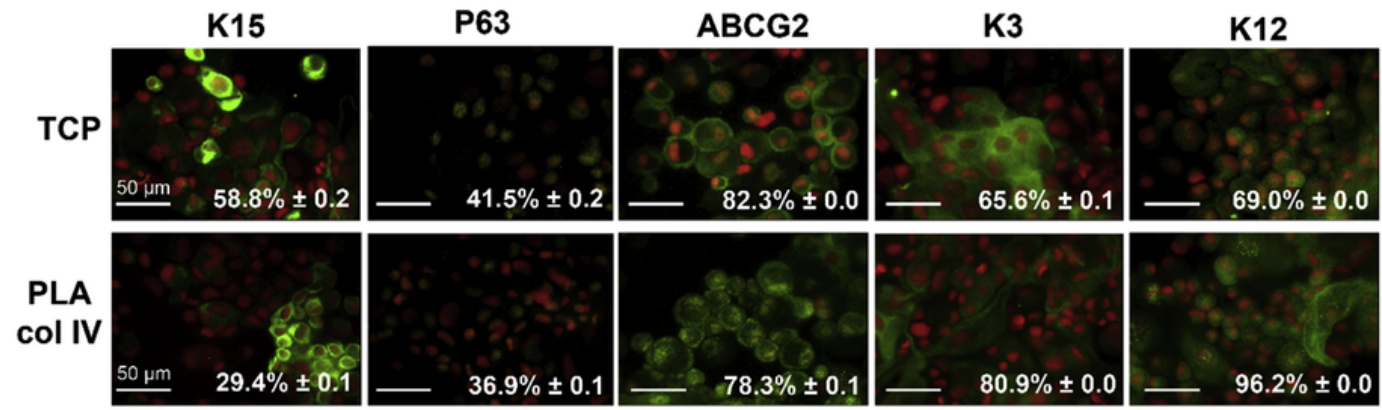

B

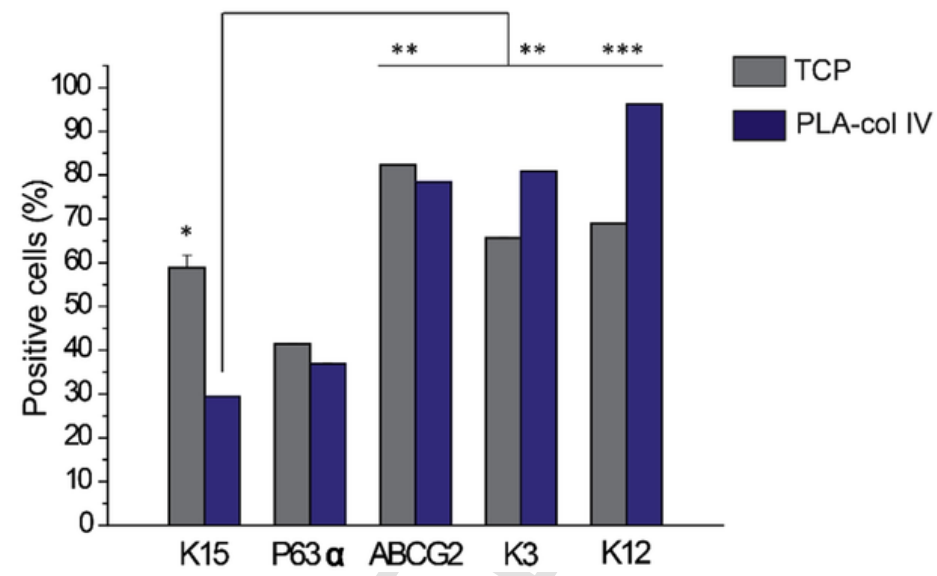

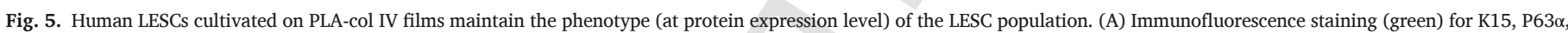

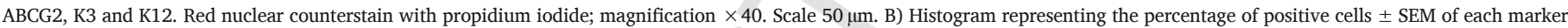

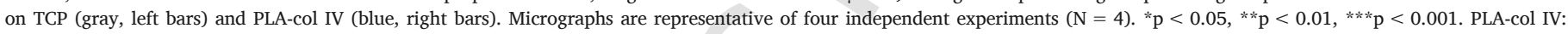
poly-L/DL-lactic acid 70:30 biopolymers functionalized with type IV collagen; TCP: tissue culture plastic; LESC: limbal epithelial stem cell.

markers, with decreased expression of corneal differentiated markers [52].

Considering all these findings, col IV was used in the present study to functionalize the PLA films, to improve the culture, attachment, and enrichment of LESCs. Col IV has been described in some studies not only as an adhesion protein, but also as a biomaterial that supports the culture of LESCs and stromal cells. Several types of collagen, such as collagen I (Vitrigel) [53], collagen III [16], or collagen together with chitosan [54] have been used for the in vitro reconstruction of the corneal epithelium [55]. Moreover, some studies have demonstrated the use of a compressed collagen matrix containing embedded fibroblasts, which simulate the corneal stroma, as substrates for LESCs $[21,24,56]$. In most of those studies, the authors tried to get a stratified and differentiated corneal epithelium using the air-lifting technique. However, in our case, this was not one of our aims because when the cells start to form more than one layer, they lose the stem cell phenotype [41]. Therefore, the aim of our work was to obtain cell monolayers in order to avoid cell differentiation and retain the stem cell-ness to further transplant a stem-cell-rich population onto the ocular surface. Furthermore, to elude non-human, animal components in the cell cultures, murine feeder cells were not used and the culture medium was free of animal supplements [18]. To our knowledge, there are no studies that have used PLA-col IV substrates with similar goals to our study, making it impossible to compare our results with any publication.

Due to the difficulty of obtaining human limbal epithelial primary cultures, a human corneal epithelial (HCE) cell line was used for a viability-cytotoxicity test to determine the biocompatibility of the PLA-col IV substrates. The PLA-col IV substrates were not toxic, and even after observing a lower cell density at the final time point of cells cultured on the polymer (compared to the ones cultured on TCP), the cell den- sity on the PLA-col IV substrates increased by approximately four times over 8 days, making this substrate a potential carrier for human corneal epithelial cells. Despite the lack of studies found on the specific interaction of this polymer with corneal epithelial cells, the successful biocompatibility results obtained with the HCE cells are in line with other studies that used analog biomaterials, and with other investigations related to collagen use for corneal epithelial cell culture [16,53,54]. Additionally, the increase in cell proliferation of HCE cells grown on PLA-col IV also coincides with other studies performed with similar materials combined with col IV.

Once biocompatibility of the PLA-col IV was demonstrated with HCEs, we wanted to try its suitability as a carrier substrate for human LESCs. To study cell adhesion from isolated cells, limbal epithelial cells were obtained by enzymatic dissociation of cadaveric human corneoscleral buttons instead of from small biopsies. The enzymatic action of dispase increased the purified isolation of corneal epithelial cells and decreased the stromal cell percentage [7,44,57]. Another advantage of using the presented technique is that it allows the initial plating cell density to be the same, making it possible to compare different experimental conditions easily.

A total of $4 \times 10^{4}$ human limbal epithelial cells $/ \mathrm{cm}^{2}$ were plated on each substrate and it was observed that the cells adhered significantly faster to the PLA-col IV films ( $2 \mathrm{~h}$ ) compared to TCP (24-48 h). As mentioned previously, some authors have described the capacity of col IV to be used as a method to select LESCs. Considering this, the biopolymer used in the present work could not only improve the attachment capacity of LESCs, but also the selection and enrichment of a stem cell population. In order to test the maintenance of the stem cell population, the expression of LESC and differentiated corneal epithelial cell markers was analyzed. At the mRNA level, the expression of the 
LESC specific marker, K15, was significantly higher in limbal epithelial cells grown on PLA-col IV compared to the expression in the same cells cultured on TCP. Moreover, K15 expression was also greater than some differentiated corneal epithelial cell markers (K3 and K12), and the relative expression of P63 $\alpha$ (another specific marker of LESCs) was also higher than the expression of $\mathrm{K} 3$ in limbal epithelial cells cultured on the PLA-col IV substrates. Considering all this data together, our results suggest that the PLA-col IV substrate, apart from improving the LESC attachment to the surface, can maintain the undifferentiated stem cell phenotype of these cells.

At the protein level, the percentage of cells expressing p63 $\alpha$ and ABCG2 was similar in limbal epithelial cells cultured on PLA-col IV and TCP. However, the percentage of cells expressing the LESC marker, K15, was lower than the percentage of cells that expressed ABCG2, K3, or K12. The mRNA and protein expression results might seem contradictory, but the parameters analyzed were different in each technique. Relative mRNA quantification was completed using real time PCR, while the percentage of cells expressing each protein was calculated by immunofluorescence, where a quantitative expression level for each protein was not determined. Previous reports have shown that only around $5-10 \%$ of cells present in the limbal niche are undifferentiated stem cells $[2,58]$, so as expected, the percentage of cells grown on PLA-col IV expressing LESC markers (K15 and P63 $\alpha$ ) was lower than the percentage of cells expressing K3 and K12 as corneal epithelial cell markers. Nevertheless, due to the fact that only $5-10 \%$ of the limbal cells are stem cells [](58) $[2,58]$, the percentage of cells found on PLA-col IV films expressing $\mathrm{K} 15, \mathrm{P} 63 \alpha$, and $\mathrm{ABCG} 2$ should be considered as adequate.

\section{Conclusion}

Our results demonstrate that PLA-col IV films are suitable for the attachment, proliferation, and maintenance of a stem-cell-containing population of limbal epithelial cells, and support the use of synthetic biopolymers as carrier substrata for the transplantation of limbal epithelial cells onto the ocular surface.

\section{Conflict of interest}

No competing financial interests exist.

\section{Acknowledgments}

This work was supported by the Carlos III National Institute of Health, Spain (CIBER-BBN and Spanish Network on Cell Therapy, (TerCel RD12/0019/0036), MINECO/FEDER, EU), and the Castilla y León Regional Government, Spain (Regional Center for Regenerative Medicine and Cell Therapy, SAN673/VA/28/08 and SAN126/VA11/09). M. López-Paniagua and S. Galindo were supported by scholarships co-financed by the Castilla y Leon Regional Government and the European-Social-Fund. We thank M. F. de la Paz, MD, (Barraquer Eye Bank of Barcelona, Spain) for providing human corneoscleral tissues. We also thank J.M. Herreras, MD, for his clinical advice, V. Sáez for her initial technical support and I. Fernández (Statistics Unit, IOBA, University of Valladolid, Spain) for statistical assistance.

\section{References}

[1] S. Ahmad, F. Figueiredo, M. Lako, Corneal epithelial stem cells: characterization, culture and transplantation., Regen. Med. 1 (January 1) (2006) 29-44, [Internet] [cited 2018 May 16] Available from: http://www.ncbi.nlm.nih.gov/pubmed/ 17465818.

[2] R.M. Lavker, G. Dong, S.Z. Cheng, K. Kudoh, G. Cotsarelis, T.T. Sun, Relative proliferative rates of limbal and corneal epithelia. Implications of corneal epithelial migration, circadian rhythm, and suprabasally located DNA-synthesizing keratinocytes, Invest. Ophthalmol. Vis. Sci. 32 (May 6) (1991) 1864-1875, [Internet] [cited 2018 May 16]Available from: http://www.ncbi.nlm.nih.gov/pubmed/ 2032808.

[3] U. Schlötzer-Schrehardt, F.E. Kruse, Identification and characterization of limbal stem cells, Exp. Eye Res. 81 (September 3) (2005) 247-264, [Internet] [cited 2018 May 16] Available from: http://linkinghub.elsevier.com/retrieve/pii/ S0014483505000801.

[4] K.R. Kenyon, S.C. Tseng, Limbal autograft transplantation for ocular surface disorders, Ophthalmology 96 (May 5) (1989) 709-722, [Internet] [cited 2018 May 16]discussion 722-3. Available from http://www.ncbi.nlm.nih.gov/pubmed/ 2748125.

[5] Q. Le, J. Xu, S.X. Deng, The diagnosis of limbal stem cell deficiency, Ocul. Surf. 16 (May 1) (2018) 58-69, [Internet] [cited 2018 May 16] Available from http:// www.ncbi.nlm.nih.gov/pubmed/29113917.

[6] G. Pellegrini, C.E. Traverso, A.T. Franzi, M. Zingirian, R. Cancedda, M. De Luca, Long-term restoration of damaged corneal surfaces with autologous cultivated corneal epithelium, Lancet (London, England) 349 (April 9057) (1997) 990-993, [Internet]5 [cited 2018 May 16] Available from http://linkinghub.elsevier.com/ retrieve/pii/S0140673696111880.

[7] N. Koizumi, T. Inatomi, T. Suzuki, C. Sotozono, S. Kinoshita, Cultivated corneal epithelial stem cell transplantation in ocular surface disorders, Ophthalmology 108 (May 9) (2001 Sep) 1569-1574, [Internet] [cited 2018 16] Available from http:// www.ncbi.nlm.nih.gov/pubmed/11535452.

[8] V.S. Sangwan, H.P. Matalia, G.K. Vemuganti, A. Fatima, G. Ifthekar, S. Singh, et al., Clinical outcome of autologous cultivated limbal epithelium transplantation, Indian J. Ophthalmol. 54 (March 1) (2019) 29-34, [Internet]. 2006 [cited 2018 May 16] Available from: http://www.ncbi.nlm.nih.gov/pubmed/16531667.

[9] P. Rama, S. Matuska, G. Paganoni, A. Spinelli, M. De Luca, G. Pellegrini, Limbal stem-cell therapy and long-term corneal regeneration, N. Engl. J. Med. 363 (July 2) (2010) 147-155, [Internet]8 [cited 2018 May 16] Available from: http://www. ncbi.nlm.nih.gov/pubmed/20573916.

[10] B.E. Ramírez, A. Sánchez, J.M. Herreras, I. Fernández, J. García-Sancho, T. Nieto-Miguel, et al., Stem cell therapy for corneal epithelium regeneration following good manufacturing and clinical procedures, Biomed. Res. Int. (2015), 408495 [Internet]. [cited 2018 May 16]Available from http://www.hindawi.com/journals/ bmri/2015/408495/.

[11] P. Rama, S. Bonini, A. Lambiase, O. Golisano, P. Paterna, M. De Luca, et al., Autologous fibrin-cultured limbal stem cells permanently restore the corneal surface of patients with total limbal stem cell deficiency, Transplantation 72 (November 9) (2001) 1478-1485, [Internet]15 [cited 2018 May 16] Available from http://www. ncbi.nlm.nih.gov/pubmed/11707733.

[12] N. Koizumi, T. Inatomi, A.J. Quantock, N.J. Fullwood, A. Dota, S. Kinoshita, Amniotic membrane as a substrate for cultivating limbal corneal epithelial cells for autologous transplantation in rabbits, Cornea 19 (January 1) (2000) 65-71, [Internet] [cited 2018 May 16] Available from: http://www.ncbi.nlm.nih.gov/pubmed/ 10632011.

[13] S. Yoshida, S. Shimmura, T. Kawakita, H. Miyashita, S. Den, J. Shimazaki, et al., Cytokeratin 15 can be used to identify the limbal phenotype in normal and diseased ocular surfaces, Investig. Opthalmol. Vis. Sci. 47 (11) (2006) 4780, [Internet]. 1 [cited 2018 May 16] Available from http://www.ncbi.nlm.nih.gov/ pubmed/17065488

[14] S.C.G. Tseng, D. Meller, D.F. Anderson, A. Touhami, R.T.F. Pires, M. Grüterich, et al., Ex vivo preservation and expansion of human limbal epithelial stem cells on amniotic membrane for treating corneal diseases with total limbal stem cell deficiency, Adv. Exp. Med. Biol (2002), [Internet] [cited 2018 May 16];506 (Pt B):1323-34. Available from: http://www.ncbi.nlm.nih.gov/pubmed/12614074.

[15] X. Zhu, R.W. Beuerman, M.B.E. Chan-Park, Z. Cheng, L.P.K. Ang, D.T.H. Tan, Enhancement of the mechanical and biological properties of a biomembrane for tissue engineering the ocular surface, Ann. Acad. Med. Singap. 35 (March (3)) (2006) 210-214, [Internet] [cited 2018 May 16] Available from: http://www.ncbi.nlm. nih.gov/pubmed/16625272.

[16] S. Dravida, S. Gaddipati, M. Griffith, K. Merrett, S. Lakshmi Madhira, V.S. Sangwan, et al., A biomimetic scaffold for culturing limbal stem cells: a promising alternative for clinical transplantation, J. Tissue Eng. Regen. Med. 2 (July 5) (2008) 263-271, https://doi.org/10.1002/term.91, [Internet] [cited 2018 May 16] Available from:.

[17] L.P.K. Ang, Z.Y. Cheng, R.W. Beuerman, S.H. Teoh, X. Zhu, D.T.H. Tan, The development of a serum-free derived bioengineered conjunctival epithelial equivalent using an ultrathin poly(epsilon-caprolactone) membrane substrate, Invest. Ophthalmol. Vis. Sci. 47 (January1) (2006) 105-112, https://doi.org/10.1167/iovs. 05-0512, [Internet] 1 [cited 2018 May 16] Available from: http://iovs.arvojournals.org/article.aspx?

[18] A. de la Mata, T. Nieto-Miguel, M. López-Paniagua, S. Galindo, M.R. Aguilar, L García-Fernández, et al., Chitosan-gelatin biopolymers as carrier substrata for limbal epithelial stem cells, J. Mater. Sci. Mater. Med. 24 (December 12) (2013) 2819-2829, [Internet]28 [cited 2018 May 16] Available from http://www.ncbi. nlm.nih.gov/pubmed/23892486

[19] Y. Minami, H. Sugihara, S. Oono, Reconstruction of cornea in three-dimensional collagen gel matrix culture, Invest. Ophthalmol. Vis. Sci. 34 (June 7) (1993) 2316-2324, [Internet] [cited 2018 May 16] Available from: http://www.ncbi.nlm. nih.gov/pubmed/7685009.

[20] A. Niiya, Y. Matsumoto, T. Ishibashi, K. Matsumoto, S. Kinoshita, Collagen gel-embedding culture of conjunctival epithelial cells, Graefes. Arch. Clin. Exp. Ophthalmol. 235 (January 1) (1997) 32-40, [Internet] [cited 2018 May 16] Available from: http://www.ncbi.nlm.nih.gov/pubmed/9034840. 
[21] H.J. Levis, R.A. Brown, J.T. Daniels, Plastic compressed collagen as a biomimetic substrate for human limbal epithelial cell culture, Biomaterials 31 (October 30) (2010) 7726-7737, [Internet] [cited 2018 May 16]Available from: http:// linkinghub.elsevier.com/retrieve/pii/S0142961210008537.

[22] H. Martínez-Osorio, M. Juárez-Campo, Y. Diebold, A. Girotti, M. Alonso, F.J. Arias, et al., Genetically engineered elastin-like polymer as a substratum to culture cells from the ocular surface, Curr. Eye Res. 34 (January (1)) (2009) 48-56, https://doi. org/10.1080/02713680802542053, [Internet]2 [cited 2018 May 16] Available from:

[23] P. Deshpande, M. Notara, N. Bullett, J.T. Daniels, D.B. Haddow, S. MacNeil, Development of a surface-modified contact lens for the transfer of cultured limbal epithelial cells to the cornea for ocular surface diseases, Tissue Eng. Part. A 15 (October 10) (2009) 2889-2902, [Internet] [cited 2018 May 16] Available from: http:// www.ncbi.nlm.nih.gov/pubmed/19265461.

[24] S. Mi, B. Chen, B. Wright, C.J. Connon, Plastic compression of a collagen gel forms a much improved scaffold for ocular surface tissue engineering over conventional collagen gels, J. Biomed. Mater. Res. Part. A 95A (July 2) (2010) 447-453, [Internet]20 [cited 2018 May 16] Available from: http://www.ncbi.nlm.nih.gov/ pubmed/20648540.

[25] K.N. Nguyen, S. Bobba, A. Richardson, M. Park, S.L. Watson, D. Wakefield, et al., Native and synthetic scaffolds for limbal epithelial stem cell transplantation, Acta Biomater. 65 (January) (2018) 21-35, [Internet]20 [cited 2018 May 16] [cited 2018 May 16] Available from: http://linkinghub.elsevier.com/retrieve/pii/ S1742706117306657.

[26] B. Sudha, H.N. Madhavan, G. Sitalakshmi, J. Malathi, S. Krishnakumar, Y. Mori, et al., Cultivation of human corneal limbal stem cells in mebiol gel--a thermo-reversible gelation polymer, Indian J. Med. Res. 124 (December (6)) (2006) 655-664, [Internet] [cited 2018 May 16] Available from: http://www.ncbi.nlm. nih.gov/pubmed/17287553.

[27] G. Sitalakshmi, B. Sudha, H.N. Madhavan, S. Vinay, S. Krishnakumar, Y. Mori, e al., Ex vivo cultivation of corneal limbal epithelial cells in a thermoreversible poly mer (mebiol gel) and their transplantation in rabbits: an animal model, Tissue Eng. Part A 15 (Febraury 2) (2009) 407-415, [Internet] [cited 2018 May 16] Available from: http://www.ncbi.nlm.nih.gov/pubmed/18724830.

[28] J. Yang, M. Yamato, K. Nishida, T. Ohki, M. Kanzaki, H. Sekine, et al., Cell delivery in regenerative medicine: The cell sheet engineering approach, J. Control. Release 116 (November 2) (2006) 193-203, [Internet] 28 [cited 2018 May 16] Available from: http://www.ncbi.nlm.nih.gov/pubmed/16890320.

[29] C.A. Mills, M. Navarro, E. Engel, E. Martinez, M.P. Ginebra, J. Planell, et al., Transparent micro- and nanopatterned poly(lactic acid) for biomedical applications, J. Biomed. Mater. Res. A 76 (March 4) (2006) 781-787, https://doi.org/10.1002/ jbm.a.30539, [Internet].15 [cited 2018 May 16] Available from:

[30] K. Madhavan Nampoothiri, N.R. Nair, R.P. John, An overview of the recent developments in polylactide (PLA) research, Bioresour. Technol. 101 ((November 22) (2010) 8493-8501, [Internet] [cited 2018 May 16] Available from: http:// linkinghub.elsevier.com/retrieve/pii/S0960852410009508.

[31] A.G. Andreopoulos, E. Hatzi, M. Doxastakis, Synthesis and properties of poly(lactic acid), J. Mater. Sci. Mater. Med. 10 (January1) (1999) 29-33, [Internet] [cited 2018 May 16] Available from: http://www.ncbi.nlm.nih.gov/pubmed/15347991.

[32] A. Heymer, G. Bradica, J. Eulert, U. Nöth, Multiphasic collagen fibre-PLA composites seeded with human mesenchymal stem cells for osteochondral defect repair: an in vitro study, J. Tissue Eng. Regen. Med. 3 (July5) (2009) 389-397, https:// doi.org/10.1002/term.175, [Internet] [cited 2018 May 16] Available from:

[33] M.D. Schofer, U. Boudriot, C. Wack, I. Leifeld, C. Gräbedünkel, R. Dersch, et al., Influence of nanofibers on the growth and osteogenic differentiation of stem cells: a comparison of biological collagen nanofibers and synthetic PLLA fibers, J. Mater. Sci. Mater. Med. 20 (March 3) (2009) 767-774, [Internet]6 [cited 2018 May 16] Available from: http://www.ncbi.nlm.nih.gov/pubmed/18987945.

[34] A. Gregor, E. Filová, M. Novák, J. Kronek, H. Chlup, M. Buzgo, et al., Designing of PLA scaffolds for bone tissue replacement fabricated by ordinary commercial 3D printer, J. Biol. Eng. 11 (December (1)) (2017) 31, [Internet]16 [cited 2018 May 16] Available from: http://jbioleng.biomedcentral.com/articles/10.1186/ s13036-017-0074-3.

[35] S.Y. Lee, J.H. Oh, J.C. Kim, Y.H. Kim, S.H. Kim, J.W. Choi, In vivo conjunctival reconstruction using modified PLGA grafts for decreased scar formation and contrac tion, Biomaterials 24 (December (27)) (2003) 5049-5059, [Internet] [cited 2018 May 16] Available from: http://www.ncbi.nlm.nih.gov/pubmed/14559019.

[36] C. Pratoomsoot, H. Tanioka, K. Hori, S. Kawasaki, S. Kinoshita, P.J. Tighe, et al., A thermoreversible hydrogel as a biosynthetic bandage for corneal wound repair, Biomaterials 29 (January 3) (2008) 272-281, [Internet] [cited 2018 May 16] Available from: http://linkinghub.elsevier.com/retrieve/pii/ S0142961207007351.

[37] Y. Amagai, K. Karasawa, J. Kyungsook, A. Matsuda, M. Kojima, J. Watanabe, et al., Development of a novel carrier optimized for cell sheet transplantation, Biomatter 5 (January 1) (2015) e1027846, https://doi.org/10.1080/21592535.2015. 1027846, [Internet]14 [cited 2018 May 16] Available from:

[38] M.A. Mateos-Timoneda, O. Castano, J.A. Planell, E. Engel, Effect of structure, topography and chemistry on fibroblast adhesion and morphology, J. Mater. Sci. Mater. Med. 25 (July 7) (2014) 1781-1787, [Internet] 26 [cited 2018 May 16] Available from: http://www.ncbi.nlm.nih.gov/pubmed/24668270.

[39] X. Punet, R. Mauchauffé, M.I. Giannotti, J.C. Rodríguez-Cabello, F. Sanz, E. Engel, et al., Enhanced cell-material interactions through the biofunctionalization of polymeric surfaces with engineered peptides, Biomacromolecules 14 (August 8) (2013)
2690-2702, https://doi.org/10.1021/bm4005436, [Internet]12 [cited 2018 May 16] Available from:

[40] U. Schlötzer-Schrehardt, T. Dietrich, K. Saito, L. Sorokin, T. Sasaki, M. Paulsson, et al., Characterization of extracellular matrix components in the limbal epithelia stem cell compartment, Exp. Eye Res. 85 (December 6) (2007) 845-860, [Internet] [cited 2018 May 16] Available from: http://linkinghub.elsevier.com/retrieve/ pii/S0014483507002461.

[41] W. Li, Y. Hayashida, Y.-T. Chen, S.C. Tseng, Niche regulation of corneal epithelial stem cells at the limbus, Cell. Res. 17 (Janurary 1) (2007) 26-36, [Internet] [cited 2018 May 16] Available from: http://www.ncbi.nlm.nih.gov/pubmed/17211449.

[42] F. Bian, W. Liu, K.-C. Yoon, R. Lu, N. Zhou, P. Ma, et al., Molecular signatures and biological pathway profiles of human corneal epithelial progenitor cells, Int. J. Biochem. Cell. Biol 42 (July 7) (2010) 1142-1153, [Internet][cited 2018 May 16] Available from: http://linkinghub.elsevier.com/retrieve/pii/ S1357272510001330

[43] K. Araki-Sasaki, Y. Ohashi, T. Sasabe, K. Hayashi, H. Watanabe, Y. Tano, et al., An SV40-immortalized human corneal epithelial cell line and its characterization, Invest. Ophthalmol. Vis. Sci. 36 (March 3) (1995) 614-621, [Internet] [cited 2018 May 16] Available from: http://www.ncbi.nlm.nih.gov/pubmed/7534282.

[44] M. López-Paniagua, T. Nieto-Miguel, A. de la Mata, M. Dziasko, S. Galindo, E. Rey, et al., Comparison of functional limbal epithelial stem cell isolation methods, Exp. Eye Res. 146 (May) (2016) 83-94, [Internet ] [cited 2018 May 16] Available from: http://linkinghub.elsevier.com/retrieve/pii/S0014483515300877.

[45] M.A. Kurpakus, M.T. Maniaci, M. Esco, Expression of keratins K12, K4 and K14 during development of ocular surface epithelium, Curr. Eye Res. 13 (November 11) (1994) 805-814, [Internet] [cited 2018 May 16] Available from: http://www.ncbi. nlm.nih.gov/pubmed/7531631.

[46] M.M. Rodrigues, J. Krachmer, S. Rajagopalan, A. Ben-Zvi, Actin filament localization in developing and pathologic human corneas, Cornea 6 (3) (1987) 190-196, [Internet][cited 2018 May 16] Available from: http://www.ncbi.nlm.nih.gov/ pubmed/3677723.

[47] A. Schermer, S. Galvin, T.T. Sun, Differentiation-related expression of a major 64K corneal keratin in vivo and in culture suggests limbal location of corneal epithelial stem cells, J. Cell. Biol. 103 (July 1) (1986) 49-62, [Internet] [cited 2018 May 16] Available from: http://www.ncbi.nlm.nih.gov/pubmed/2424919.

[48] G. Pellegrini, E. Dellambra, O. Golisano, E. Martinelli, I. Fantozzi, S. Bondanza, et al., p63 identifies keratinocyte stem cells., Proc. Natl. Acad. Sci. 98 (March 6) (2001) 3156-3161, [Internet]13 [cited 2018 May 16] Available from: http://www. ncbi.nlm.nih.gov/pubmed/11248048.

[49] X. Ding, J. Wu, C. Jiang, ABCG2: a potential marker of stem cells and novel target in stem cell and cancer therapy, Life Sci. 86 (April 17-18) (2010) 631-637, [Internet]24 [cited 2018 May 16] Available from: http://linkinghub.elsevier.com/ retrieve/pii/S0024320510000731.

[50] T. Nieto-Miguel, M. Calonge, A. de la Mata, M. López-Paniagua, S. Galindo, M.F. de la Paz, et al., A comparison of stem cell-related gene expression in the progenitor-rich limbal epithelium and the differentiating central corneal epithelium, Mol. Vis. 17 (2011) 2102-2117, [Internet] [cited 2018 May 16] Available from: http:// www.ncbi.nlm.nih.gov/pubmed/21850186.

[51] K.J. Livak, T.D. Schmittgen, Analysis of relative gene expression data using real-time quantitative PCR and the $2-\Delta \Delta \mathrm{CT}$ method, Methods 25 (December 4) (2001) 402-408, [Internet] [cited 2018 May 16] Available from: http://www.ncbi. nlm.nih.gov/pubmed/11846609.

[52] D.-Q. Li, Z. Chen, X.J. Song, C.S. de Paiva, H.-S. Kim, S.C. Pflugfelder, Partial enrichment of a population of human limbal epithelial cells with putative stem cell properties based on collagen type IV adhesiveness, Exp. Eye Res. 80 (April 4) (2005) 581-590, [Internet] [cited 2018 May 16] Available from: http://linkinghub. elsevier.com/retrieve/pii/S0014483504003410.

[53] W. McIntosh Ambrose, A. Salahuddin, S. So, S. Ng, S. Ponce Márquez, T. Takezawa, et al., Collagen vitrigel membranes for the in vitro reconstruction of separate corneal epithelial, stromal, and endothelial cell layers, J. Biomed. Mater. Res. B Appl. Biomater. 90 (August 2) (2009) 818-831, https://doi.org/10.1002/ jbm.b.31351, [Internet] [cited 2018 May 16] Available from.

[54] N. Builles, N. Bechetoille, V. Justin, V. André, V. Barbaro, Iorio E. Di, et al., Development of a hemicornea from human primary cell cultures for pharmacotoxicology testing, Cell. Biol. Toxicol. 23 (July 4) (2007) 279-292, [Internet]13 [cited 2018 May 16] Available from: http://www.ncbi.nlm.nih.gov/pubmed/17380411.

[55] A. Tidu, D. Ghoubay-Benallaoua, C. Teulon, S. Asnacios, K. Grieve, F. Portier, et al., Highly concentrated collagen solutions leading to transparent scaffolds of controlled three-dimensional organizations for corneal epithelial cell colonization, Biomater. Sci. (2018), [Internet] [cited 2018 May 16]; Available from: http://xlink. rsc.org/?DOI $=$ C7BM01163F.

[56] S. Mi, B. Chen, B. Wright, C.J. Connon, Ex vivo construction of an artificial ocula surface by combination of corneal limbal epithelial cells and a compressed collagen scaffold containing keratocytes, Tissue Eng. Part A 16 (June 6) (2010) 2091-2100, [Internet] [cited 2018 May 16] Available from: http://www.ncbi.nlm. nih.gov/pubmed/20109018

[57] S. Liu, J. Li, C. Wang, D. Tan, R. Beuerman, Human limbal progenitor cell characteristics are maintained in tissue culture, Ann. Acad. Med. Singap. 35 (Febraury 2) (2006) 80-86, [Internet] [cited 2018 May 16] Available from: http://www.ncbi. nlm.nih.gov/pubmed/16565759.

[58] S. Merjava, K. Brejchova, A. Vernon, J.T. Daniels, K. Jirsova, Cytokeratin 8 is expressed in human corneoconjunctival epithelium, particularly in limbal epithelia cells, Invest. Ophthalmol. Vis. Sci. 52 (Febraury 2) (2011) 787-794, [Internet]9 
[cited 2018 May 16] Available from: http://iovs.arvojournals.org/article. aspx?doi $=10.1167 /$ iovs.10-5489. 